Reprod. Nutr. Dévelop., 1987, 27 (1 A), 29-44.

\title{
The reproductive cycle of male and female brown trout (Salmo trutta fario) : a quantitative study
}

\author{
R. BILLARD ( $\left.{ }^{1}\right)$
}

I.N.R.A., Station de Physiologie animale, 78350 Jouy-en-Josas, France.

Summary. Gonadal development and gametogenesis have been studied in the brown trout (Salmo trutta) beginning at the establishment of the first reproductive cycle. Monthly samples were taken from 14-month old fishes beginning in July and extending over a 20month period. Complete gametogenesis was observed in males from the first year of sampling and from the following year in females. Spermatogenesis was analysed over the first two cycles and a quantitative study showed that the volume of spermatozoa produced in relation to body weight was slightly higher at the end of the second cycle. At the end of the second reproductive cycle, the process of spermiation ceased while there were still spermatozoa in the testes, although most of them had been evacuated at the end of the first cycle. Spermatogenesis seemed to be more efficient during the second cycle but spermiation yield was higher during the first cycle. Oogonia were always present in the female ovaries and there was mitotic activity in July of the second year of life and in October-November of the third year. Previtellogenetic stages (accumulation of RNA and lipid) were already present at 14 months of age when sampling started. During the second year of life there was limited accumulation of yolk in the oocytes but it did not modify total ovary weight. In this population, vitellogenesis was complete and most of the females began to ovulate only in the third year. Before the end of the cycle in October-November, the number of previtellogenetic oocytes (stages 1,2 and 3) increased markedly. This was followed in December by an increase in the number of oocytes containing yolk bodies, representing no doubt the class of oocytes undertaking vitellogenesis in the next cycle. the patterns of initiation of the first and second cycles thus appeared to be very different.

\section{Introduction.}

Past studies in salmonids have analysed the structural aspects of the reproductive cycle and the seasonal changes related to it. Weisel (1943), Oota et al. (1965), Billard et al. (1971) and Van den Hurk et al. (1978) described the histology of the trout testis. Seasonal changes in various species have been reported by Jones (1940) studying Salmo salar, Henderson (1962) Salvelinus fontinalis, Honma and Tamura (1962) Plecoglossus altivelis, Billard et al. (1978) and Billard (1983a, b) Salmo gairdneri and Salmo trutta, and Hiroi and Yamamoto (1968, 1970) and levleva (1970) some Oncorhynchus species.

(') Presend address : Museum national d'Histoire naturelle, Ichtyologie, 43 rue Cuvier, 75231 Paris Cedex 05. 
Female oogenesis and vitellogenesis have been reported by Honma and Tamura (1962), Henderson (1962) and Lusk (1968). More specific work on vitellogenesis, especially at the earliest stage of oocyte development, has been carried out by Beams and Kessel (1973), Upadhyay (1977), Upadhyay et al. (1978), Van den Hurk and Peute (1979), Breton et al. (1983), Busson-Mabillot (1984) and Sumpter et al. (1984).

In most of these studies, gametogenesis was only analysed qualitatively. In the present study, we used a previously described technique (Billard et al., 1971) to quantify the various cell types occurring in the brown trout gonad over a 20 month period. During that period, the first reproductive cycle was established in both males and females and a second cycle in males.

\section{Material and methods.}

The brown trout population used in this study has been held for several generations in the Llandegfedd fish-farm near Cardiff. The water was supplied by the Llandegfedd reservoir. The $1-\mathrm{m}^{3}$ demi-circular tank, with a flow rate of $15 \mathrm{l} / \mathrm{min}$, held $10 \mathrm{~kg}$ of fish (males and females mixed). Pelleted food was given once a day every day at a rate of $2 \%$ of body weight for immature fish and $1 \%$ of body weight for adult fish. Starting in July and extending over a 20-month period, we sampled 5 fish of each sex monthly in a batch of trout hatched in March of the previous year.

The fish, anaesthetized with $50 \mathrm{mg}$ of MS222/I, were killed and their body weight measured to the nearest gram. The gonads, liver and viscera were weighed to the nearest milligram. The pituitaries were weighed to the nearest $0.01 \mathrm{mg}$ on a Mettler electric scale. A small piece of the middle part of the gonads was fixed in Bouin-Hollande, and the weight. and volume of the sample measured. $5-\mu \mathrm{m}$ thick sections were cut at right angles to the longitudinal axis of the gonad and stained with haematoxylin-Orange G- Aniline Blue. During the experimental period from July to February, water temperature, rainfall and sunshine were measured (fig. 1). The fish were checked weekly for fungus infection and UDN disease.

Studies on spermatogenesis. - We analysed spermatogenesis quantitatively on histological sections using a No. 1 Zeiss occular integrator in the manner described for goldfish (Billard et al., 1974) and previously used for trout (Billard, 1983b.). Twenty-five points were counted on 50 microscopic fields to give the volume percentage for each stage identified. Since the total volume of both testes could be determined, a simple calculation gave the individual volume in cubic millimeters $\left(\mathrm{mm}^{3}\right)$ for each cell type. The testis volume of each individual was divided by the body weight, gonads and viscera excluded. The final results were expressed in $\mathrm{mm}^{3}$ of cells or tissues per gram of body weight, and the values (cell index in the figures) are given the confidence interval $\pm 5 \%$. The following cells or tissues were counted :

(a) somatic tissues : cyst cells (Sertoli cells), connective tissues, interstitial cells and blood vessels ; 
(b) lobule lumen: since the diameter of the lumen increases during active spermatogenesis, we measured the volume of the lumen not occupied by spermatozoa ;

(c) spermatogonia : isolated type $A$ spermatogonia $\left(G_{A}\right)$ and type $B$ spermatogonia $\left(G_{B}\right)$ included in cysts ;

(d) primary spermatocytes (spcyts): this stage corresponded to the meiotic prophase which started when the nucleolus became indistinct and the chromosomes appeared ;

(e) spermatids (spt) and secondary spermatocytes: the spermatids, having a small nucleus $(2-3 \mu \mathrm{m})$ containing condensed chromatin, were also organized into cysts. The secondary spermatocytes had a short, transient stage and were rather difficult to differentiate easily from the spermatids. The counts of these two stages were therefore combined;

(f) spermatozoa (spzoa) in the lobule lumen.

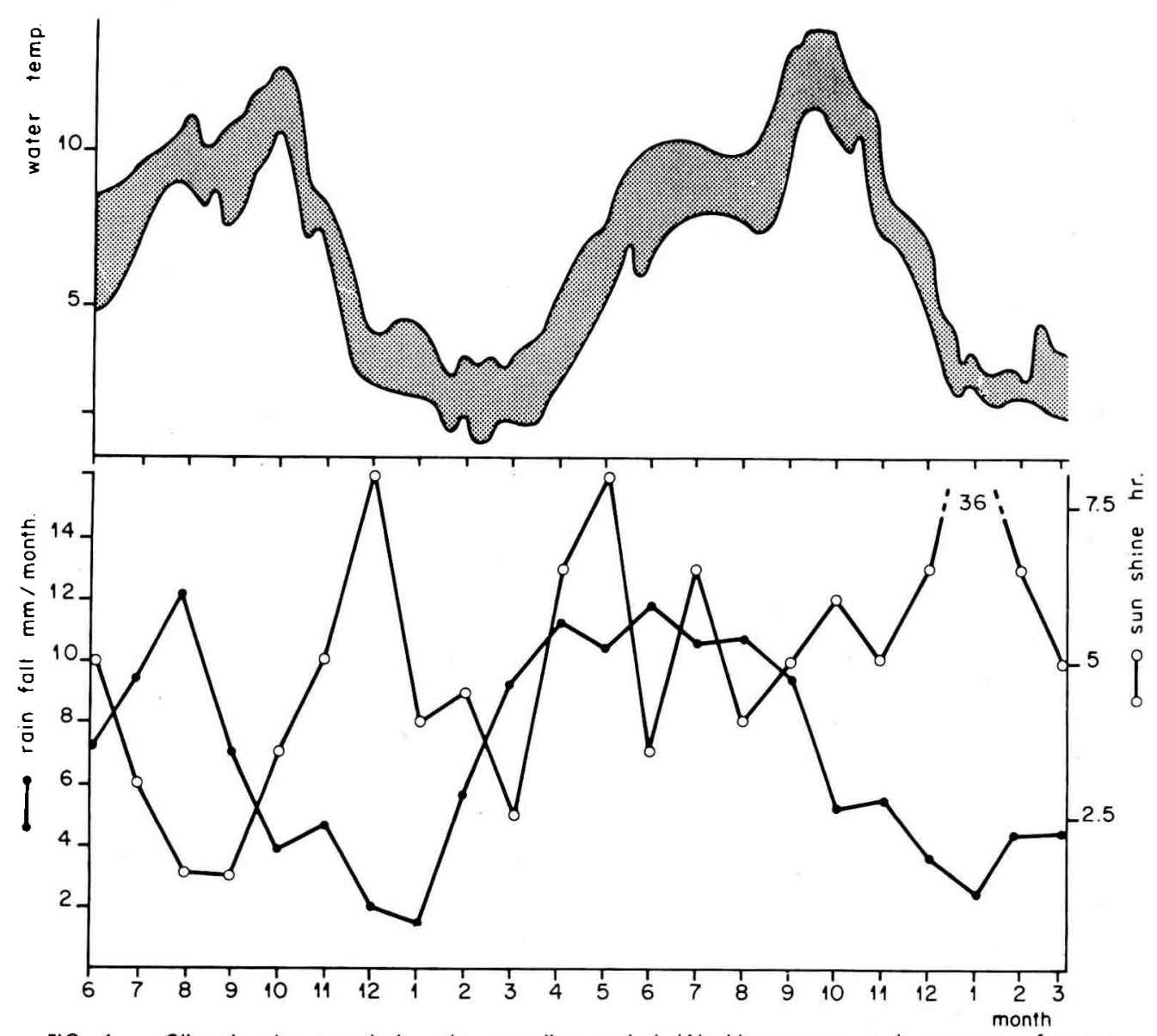

FIG. 1. - Climatic changes during the sampling period. Weekly average and extremes ō water temperature. Average daily hours of sunshine per month. Rainfall : $\mathrm{mm}$ per month (courtesy Dr. Hill).

Reproduction, Nutrition, Développement $n^{\circ} 1 \mathrm{~A} / 87 .-3$ 
Because of the wide variation in the body weight of fish sampled each month, the results were expressed in ratios of the total body weight :

(i) gonadosomatic index (GSI) $=\frac{\operatorname{gonad}(\mathrm{g}) \times 100}{\text { body weight }(\mathrm{g})}$

(ii) hepatosomatic index $(\mathrm{HPI})=\frac{\text { liver }(\mathrm{g}) \times 100}{\text { body weight }(\mathrm{g})}$

(iii) pituitary somatic index (PSI) $=\frac{\text { pituitary }(\mathrm{mg}) \times 100}{\text { body weight }(\mathrm{g})}$

Each week, the fish were examined for spermiation or " running stage ", i.e. release of sperm due to handling during the spawning period.

Studies on oogenesis. - The females were studied in the same manner; oogenesis was divided into five stages:

Stage 1 ; oogonia ; the ovary was mainly occupied by these cells, isolated or in nests, and by oocytes undergoing meiosis ;

Stage 2 : oocytes of up to $300 \mu \mathrm{m}$ in diameter, showing a Balbiani body and yolk vesicles at the oocyte periphery;

Stage 3 : larger oocytes (up to $500 \mu \mathrm{m}$ in diameter), showing lipid droplets at the nuclear periphery:

Stage 4 : oocytes of $1 \mathrm{~mm}$ in diameter, showing organization of the follicular layer and yolk bodies (according to Busson-Mabillot, 1984);

Stage 5 : considerably larger oocytes $(4-5 \mathrm{~mm}$ in diameter), showing a greater number of yolk granules and fusion at the final stage of vitellogenesis.

Atretic oocytes and somatic tissues, including the connective tissue, blood vessels and egg envelopes (thecal and follicular cells), were also measured. The results are given in $\mathrm{mm}^{3}$ for each stage in both ovaries. Seasonal variations in gonadal, liver and pituitary weight were recorded and the results expressed in percentage of body weight, as for the males.

\section{Results.}

Seasonal changes in the testes. - The seasonal changes studied over two successive sexual cycles are summarized in figures 2 and 3 . The volume of the lobule lumen, free of spermatozoa, changed with the general spermatogenetic activity of the testes (fig. 2). The volume of somatic tissue, interstitial cells, Sertoli cells and extralobular connective tissue did not vary significantly; during the cycle the total volume in both testes together was minimal in May-July, shortly before the sudden onset of spermatogenetic activity.

During the first sexual cycle, the amount of $G_{A}$ was maximal in JulySeptember when spermatogenetic activity was highest. This volume then decreased slowly until January, at which time it showed some variability between 

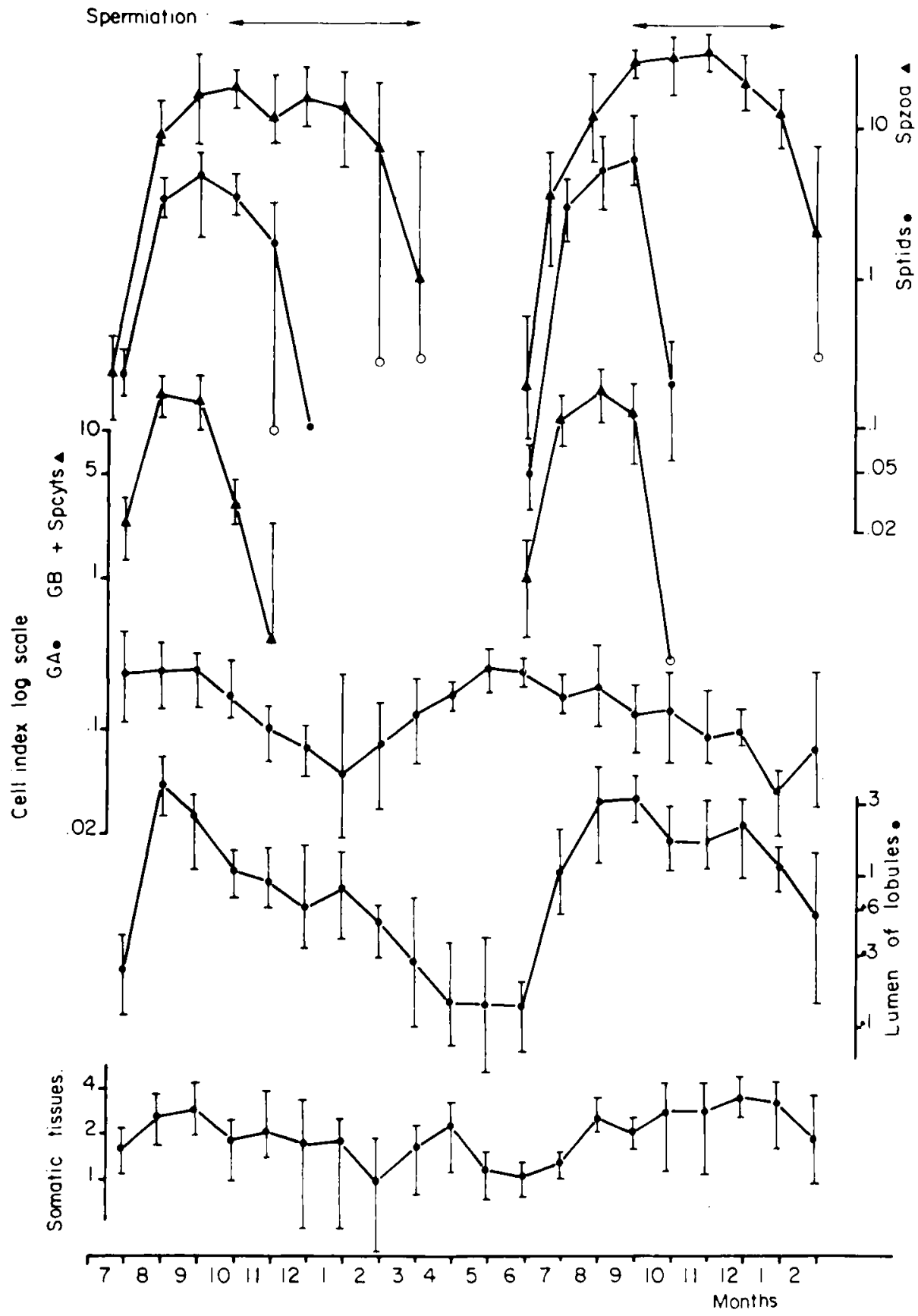

FIG. 2. - Dynamics of spermatogenesis during the sampling period. Cell index corresponds to the volume of germ cells and somatic tissues in the testis expressed in $\mathrm{mm}^{3} / \mathrm{g}$ of body weight. See text. The sign 0 indicates that some males had no cells of that category. 
males. In contrast, dramatic changes occurred in the other germ cell types $\left(G_{B}\right.$, spermatocytes, spermatids and spermatozoa). The number of these cells increased sharply in August, leading to a peak activity of the $G_{B}$ and primary spermatocytes which lasted for one month and of the secondary spermatocytes and spermatids which lasted for 2 months. A sharp drop in testis weight was observed prior to spermiation. Spermiation started in October, when the spermatids began to decrease, and ended in March. At that time, almost no spermatozoa remained in the testis, as also shown by the gonadosomatic index (GSI) (fig. 3).

The pattern of the second sexual cycle was almost the same. The first $G_{B}$ and primary spermatocytes were visible in the testis in May, although they were few in number (fig. 3). During this cycle, the spermatids had disappeared from the testis one month earlier than during the first cycle. Spermiation also started a month earlier and ended in January, although the number of remnant spermatozoa appeared to be slightly higher in the second sexual cycle. Pyknotic germ cells scattered in cysts or entirely pyknotic cysts could be seen during August-October in both cycles. It should be noted that in both cycles there was some spermatogenetic activity as early as June, leading to the formation of a few scattered spermatozoa in the lumen of the lobules which started to be well organized only at that time.

Seasonal changes in the ovaries. - During the first year of sampling, no ripe hen fish were detected; the females became mature when they reached 30 months of age. The patterns of the two successive seasons studied were quite different. During the first year of sampling, germ cells at stages 1 and 2 (plotted together on fig. 4) remained at the same level. Stage 3 cells increased gradually untill January, stayed at that level until May and then decreased sharply during the next 2 months. This long-lasting peak led to a small rise in the total volume of the cells in stage 4 in January. This phenomenon, occuring in only a few of the females examined, was followed later by a second, higher peak in all females in June and July; the latter peak was probably the origin of the onset of stage 5 and mature oocytes. At that time, stage 1 and 2 oocytes, which were few, showed a sharp peak in November. Similarly, stage 3 oocytes increased in the same proportion. These peaks were followed by a small rise of stage 4 oocytes which were probably destined to reach stage 5 and full vitellogenesis later. Somatic tissues increased gradually from May to November and decreased sharply within a month. Various cell types were involed in the seasonal change of the "somatic tissue ". In June-July, the connective tissue increased, and in August-September, the follicular and thecal cells surrounding the atretic eggs enlarged. During August-october, the total volume of follicular and thecal cells increased. The volume of somatic tissue and blood vessels outside the follicle also augmented. After ovulation in November, the follicular cells expanded into the empty follicle, resulting in a sharp increase in somatic tissue volume. Atretic eggs were numerous in August and September (fig. 4). Some atresia also occurred in December as a consequence of the poor transformation of stage 3 into stage 4 . Mitosis were observed in some females in July of their second year and in October-November of their third year. During October, the interstitial tissues, 

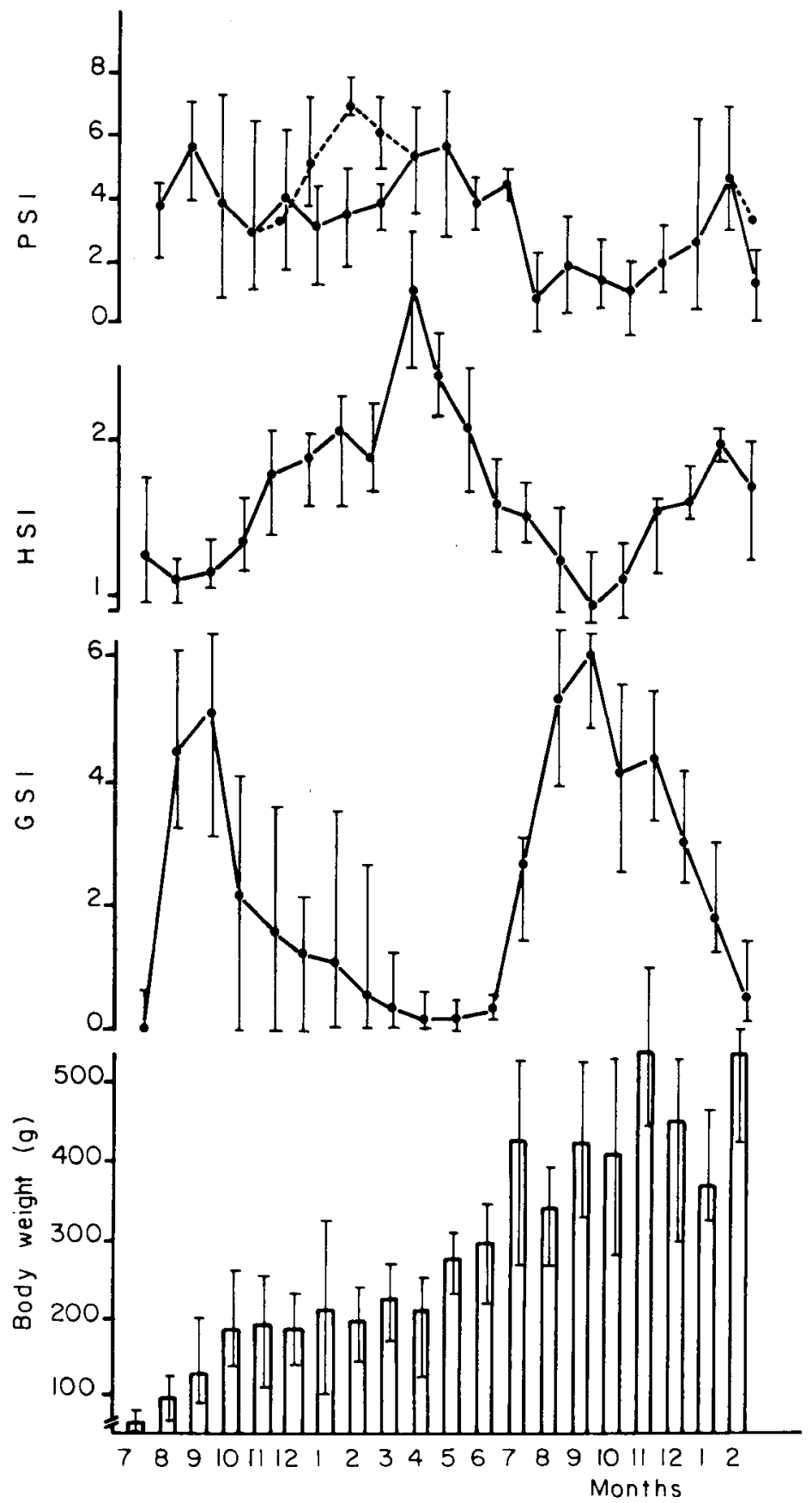

FIG. 3. - Changes in body weight, GSI, HSI and PSI in males during the sampling period $\bullet---\bullet m a l e s$ showing UDN disease. 


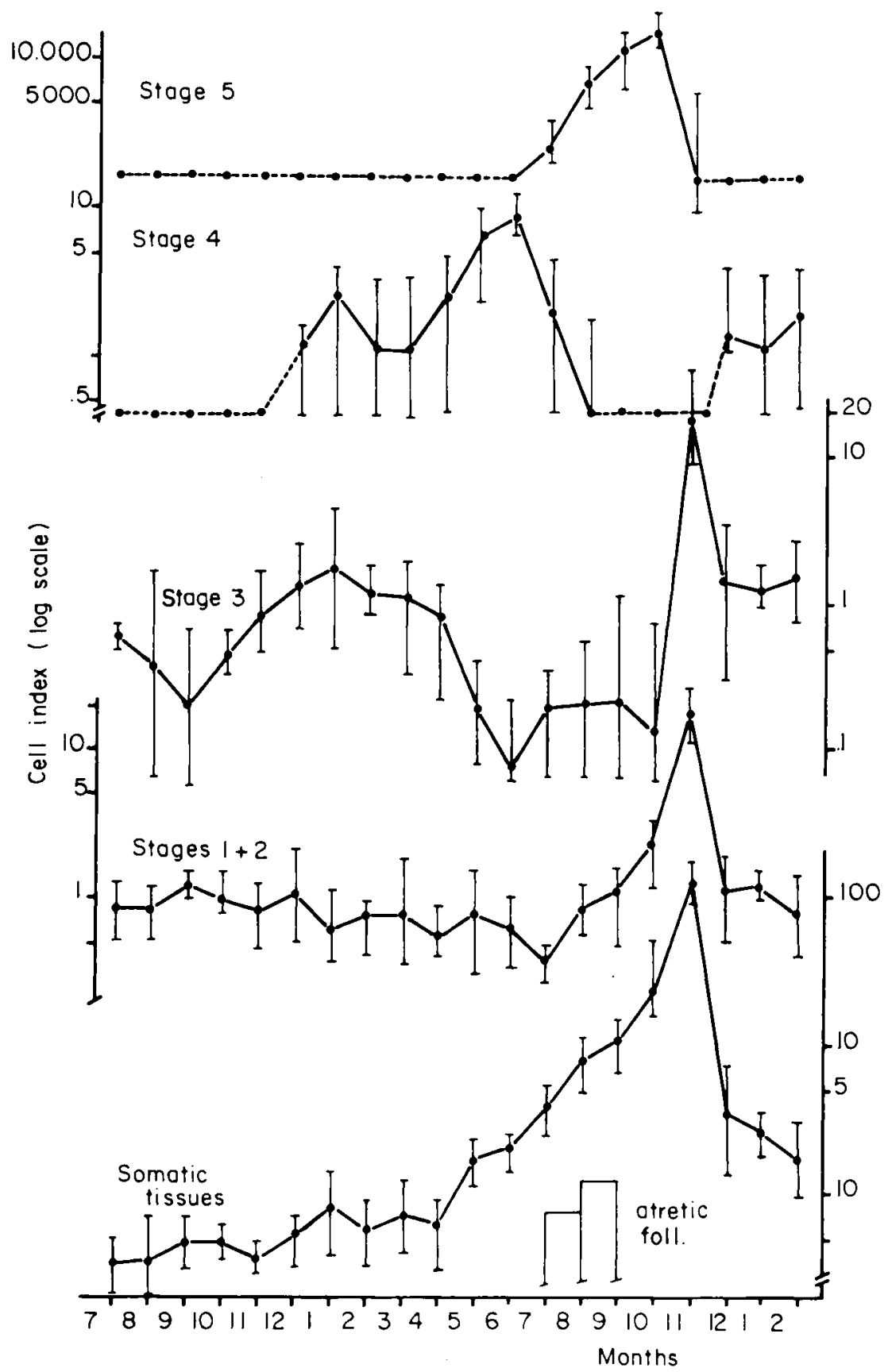

FIG. 4. - Evolution of oogenesis in brown trout during the first sexual cycle. Somatic and germinal tissues divided into 5 stages are expressed according to cell index (see legend of figure 2 and text). The sign 0 indicates that some males had no cells of that category. 
including the theca, were considerably distended. Some nests of special thecal cells (Hoar and Nagahama, 1978) were present. Numerous blood and lymph vessels were filled with material which precipitated like a network during fixation. Vacuoles could also be seen in the follicular cells, especially in atretic follicies.

Seasonal changes in pituitary and liver weights. - Male pituitary weight tended to be higher during the resting period and lower during the period of high testicular activity, but differences in the pituitary somatic index (PSI) (fig. 2) were small and insignificant. Changes in liver weight were more obvious, although individual variability was great. The hepatosomatic index (HSI) (fig. 2) was maximal at the beginning of the resting stage. It decreased in April-June, i.e. before high spermatogenetic activity in the testis. It was found that the pituitaries of UDN-affected fish were heavier than those of non-UDN fish, especially in the first sexual cycle in January (fig. 3 ).

Changes in the weight of female ovaries, liver and pituitary are shown in figure 5. The GSI was high in September-November due to the development of the final stage of vitellogenesis (stage 5). Ovarian enlargement was significant only after July when the fish were in their third year. The HSI, distributed over a wide range, showed a peak before the onset of gross ovarian enlargement. The mean PSI did not show wide variations during the 20 -month study, although the individual values were quite variable. The PSI was minimal when ovarian growth was maximal.

\section{Discussion.}

Seasonal changes in males. - During the first and second reproductive cycles of the brown trout, the first spermatogenetic waves were observed in May but the testis weight increased very sharply only in July (tenfold increase within one month). The GSI reached $5 \%$ during the first sexual cycle and $6 \%$ during the second one. Widosky and Cooper (1966) showed that the GSI was lower in young than in adult brook trout, but in contrast, Brown and Kamp (1942) could not detect any relationship between age and testicular weight in brown trout. Within this period of one month, the lobules were filled with spermatozoa, showing that spermatogenesis is a very rapid process in brown trout, as in other salmonids (Jones, 1940 ; Henderson, 1962 ; Billard, 1983a,b), herring (Bowers and Holliday, 1961) and cyprinids (Shikhshabekov, 1974). In September and October there were still high amounts of $G_{B}$, spermatocytes and spermatids, but no further increase in the number of spermatozoa ; as spermiation had not started, the transformation of spermatids into spermatozoa would seem to be inefficient during the final part of the spermatogenetic cycle. This may be reflected partly in the loss of testis weight just prior to the onset of spermiation, as previously observed in the same species (Billard, 1983b).

In the light microscopy study, all spermatogonia $\left(\mathrm{G}_{\mathrm{A}}\right)$ were seen in the Sertoli layer inside the lobule, but none were identified in the interstitial tissue or the inter-lobular space, as indicated in rainbow trout by van den Hurk et al. (1978). No signs of degeneration were evident in these spermatogonia as in those of 

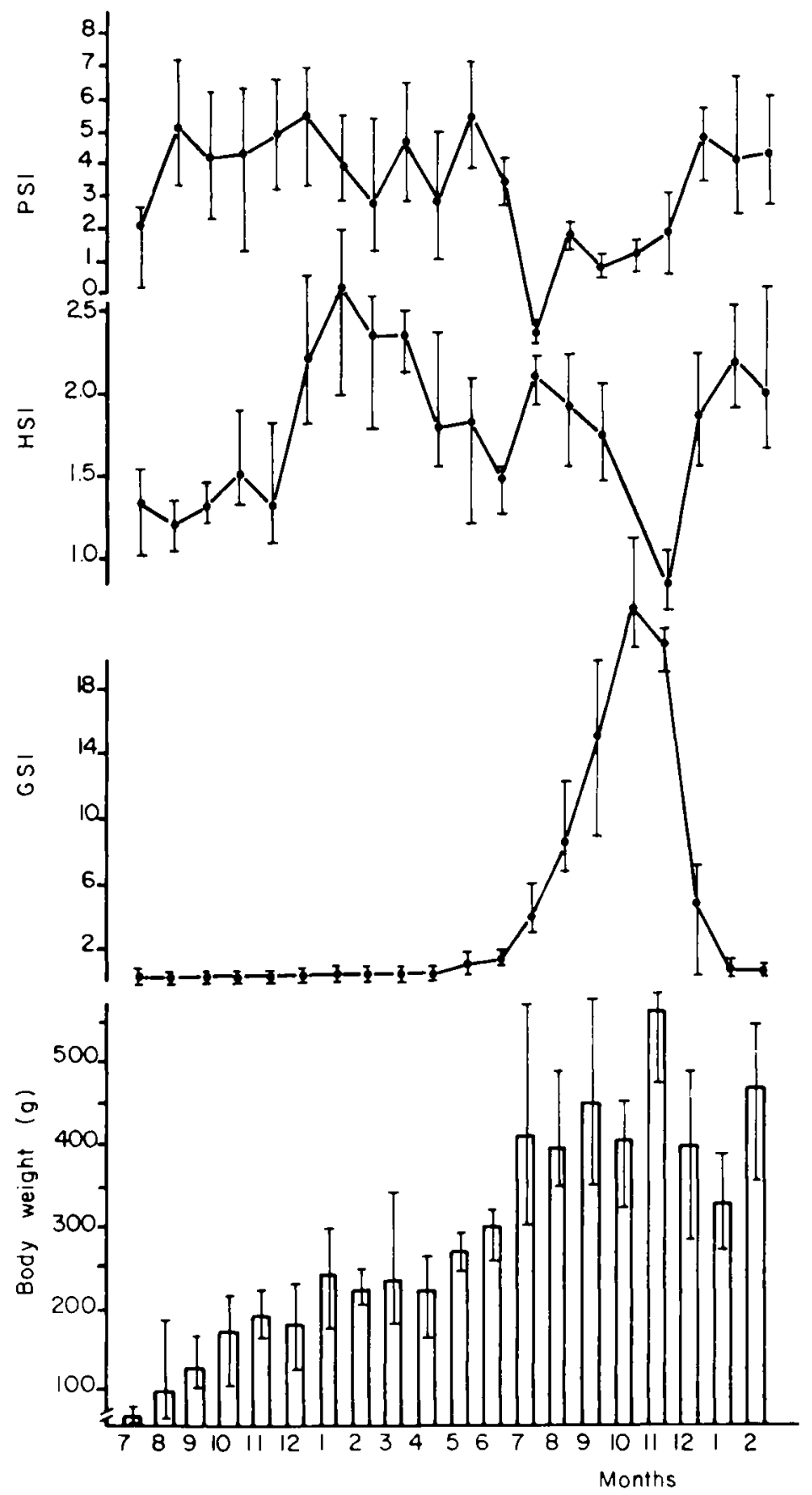

FIG. 5. - Evolution of female body weight, GSI, HSI and PSI during the 20-month sampling period. 
other species (Oncorhynchus: Weisel, 1943; Plecoglossus altivelis: Suzuki, 1939) after the first reproductive cycle.

Spermiation started 2 months after spermatogenesis was completed and lasted 4 or 5 months. Sperm release was observed 2 weeks before the first ovulation in the females in November. After the first sexual cycle was completed, almost all the spermatozoa had disappeared from the testis by the end of the spermiation period. In contrast, during the second sexual cycle, spermiation stopped before the testes were emptied of spermatozoa. A difference in the spermiation efficiency of the first and subsequent sexual cycles has been demonstrated in rainbow trout (Billard et al., 1971; Billard, 1974). In the present study in brown trout the difference in the yield of spermiation might have been due to the age of the males, but it should be pointed out that the thermal regime was very different during the two reproductive seasons. In addition, there are inter-strain differences in the spermiation patterns of rainbow trout (Baynes and Scott, 1985).

As compared to ovulation in females which did not exceed one month, the males produced sperm for a relatively long time (4-5 months). The quality of salmonid sperm and its fertilizing ability decrease as the period of spermiation progresses (Kazakov, 1979 ; Billard, 1980) so that the period during which good quality sperm, suitable for fertilization is produced, is shorter than the actual period during which the sperm is collected. In nature and in the actual management of hatchery brood stock, only a small part of the spermatogenetic production is used to fertilize the eggs.

The increase in male liver weight, which reached $3 \%$ of body weight in this study before the onset of spermatogenetic activity, was not observed by Nomura (1963) in rainbow trout males. In our study, the male HSI was even higher than the female HSI.

Seasonal changes in females. - During the first year of observation, while the males were in the first spermatogenetic cycle, vitellogenetic activity was seen in some females; lipid droplets and even yolk granules were found in some oocytes, but the final step, marked by oocyte enlargement, was not reached that year and the GSI did not show any change. The following year, a new batch of stage 4 oocytes was successfully oriented to full vitellogenesis in early August. The first oogenetic cyle originated directly from germ cells which had begun meiosis before July, i.e. in females 14 months old or less. The origin of the wave of the second cycle is not clear. A dramatic increase in the volume of stage 1 and 2 germ cells was observed at spawning time. Such a rise was not seen to occur in the previous year, showing the difference between the first and second cycles. This sudden reapparence of young oocytes after ovulation, in contrast to their scarcity in the ripe ovary, is usually considered as an illusion resulting from the expulsion of the main oocyte class at ovulation (Hickling, 1930). But in the present study, the technique used gives the true volume of young oocytes in the entire ovary. The rise in oocyte volume corresponded to a rise in the number of oocytes, although many of them were larger after spawning; this rise was probably due to new oogonial recruitment since mitosis were observed in October and November. It is likely that this new batch of stage 1 and 2 oocytes would be 
involved in the rise of oocytes in stage 3 and then in stage 4, the starting point of the oocyte wave undertaking the second vitellogenetic cycle, but it is not sure that the rise of stage 3 oocytes derived directly from the newly recruited meiotic oocytes. It is more likely that stage 3 resulted from stage 2 oocytes remaining in the ovaries from the previous year. There are some arguments for this. Repeated injection of salmon pituitary extract in immature fish initiates vitellogenesis only after several months of treatment (Funk et al., 1973 ; Upadhyay et al., 1978 ; Magri, 1980). A « maturation " period seems necessary before the young oocyte can begin to internalize yolk protein. The length of the entire period of cytoplasmic differentiation is 2 years in brown trout according to Busson-Mabillot (1984).

Sumpter et al. (1984) observed that stage 4 oocytes were already present immediately after spawning in rainbow trout. Such oocytes are ready to undertake the final step of the oogenetic cycle, that is vitellogenesis. Under adequate stimulation (for instance, advancing the decreasing photoperiod), the next full vitellogenesis can be initiated soon after ovulation in rainbow trout (Billard and Breton, 1977 ; Whitehead et al., 1978) as well as in brown trout (De Frémont and Billard, unpublished data) and oocytes are probably recruited from stage 3 and 4 oocytes present in the ovary at that time. The same way applies to females which have two reproductive cycles the same year under normal conditions (Aida et al., 1983) or under an adequate photoperiodic regime (Scott et al., 1984 ; Breton et al., 1985). It appears then that a class of oocytes can always be recruited in the ovary for vitellogenesis and that this class cannot be newlyformed oocytes. The length of the entire oogenetic cycle is then more than one year.

The situation is therefore quite different in females than in males where exogenous gonadotropin stimulation at $10^{\circ} \mathrm{C}$ results in complete spermatogenesis in 6-month immature trout (Magri, 1980). The entire gametogenetic cycle is thus much shorter in males than in females, which would explain why males usually mature earlier than females (Taube, 1976).

At first maturation, mean ovarian weight reached $22 \%$ of body weight, which is similar to or even slightly higher than other values reported for salmonids (Greene, 1926 ; Vladykov, 1956 ; Hanson and Wickwire, 1967). Wydoski and Cooper (1966) found that the GSI value was lower in young females and adult females when they were raised in infertile streams. In that experiment, the feeding rate was high; the relationship between high diet level and high fecondity (number of eggs at maturity) is now well established in salmonids (Scott, 1962 ; Martin, 1970) and in other species of fish (Woodhead, 1960 ; Wooton, 1979).

Egg atresia, similar to that described by Vladykov (1956) and to a lesser extent by Henderson (1962), was observed in August and September during the secondary growth phase of the oogenetic cycle. The increase in somatic tissue, mainly due to the hypertropic granulosa cells (follicular cells) probably corresponded to the resorption of these atretic eggs (preovulatory atretic eggs), as suggested by Honma and Tamura (1962) in Plecoglossus altivelis and by Beach (1959) in Carassius auratus. During the total period of oocyte growth, the increased volume of somatic tissue was also due to the interstitial tissue and the 
thecal cells which enlarged before and after ovulation, as observed in other salmonids (Szöllösi et al., 1978 ; Nagahama et al., 1978) and in other teleost fish (Lambert, 1969 ; Pantic and Lovren, 1973). The presence of vitellogenin-like material in interstitial tissue was also mentioned in Plecoglossus altivelis (Honma and Tamura, 1962).

The relationship between liver and ovary weights in this study is in agreement with that described for other salmonids by Nomura (1963) and Larson (1973). During the second year of life, female HSI increased in December and similarly at about the same time the following year, when the first sexual cycle had been completed.

Reçu en septembre 1986. Accepté en octobre 1986.

Aknowledgements. - We wish to thanks Mrs A. M. Escaffre for her skillful technical assistance and Mrs A. Daifuku who edited the English text. This research was partly supported by the C.N.R.S., Paris, ATP 449904. R. B. was the recipient of a British Council fellowship. This work was carried out in cooperation with the Fish Disease Laboratory at Weymouth. Collaboration and discussion with Dr. Barry Hill who supervised the maintenance of the fish, collected the samples and identified UDN disease are acknowledged.

Résumé. Etude quantitative de la gamétogenèse mâle et femelle chez la truite fario.

La gamétogenèse de la truite fario a été étudiée lors du premier cycle reproducteur à partir de prélèvements mensuels de gonades entre le $14^{\mathrm{e}}$ et le $34^{\mathrm{e}}$ mois $\mathrm{d}^{\prime}$ âge. La gamétogenèse complète a été observée dans la première année de prélèvement chez le mâle et un an plus tard chez la femelle. L'analyse de la spermatogenèse, étudiée lors de deux cycles successifs, montre que la quantité de spermatozoïdes produits, exprimée par unité de poids corporel, est légèrement plus élevée à la fin du deuxième cycle. Cependant, à cette époque, le processus de spermiation avait cessé, alors qu'il restait encore des spermatozoïdes dans les testicules, lesquels avaient été pratiquement tous évacués à la fin du premier cycle. L'efficacité de la spermatogenèse apparaît meilleure au cours du deuxième cycle, alors que le rendement de la spermiation est meilleure durant le premier cycle. Chez la femelle, des oogonies sont présentes en permanence dans les ovaires et une activité mitotique a été identifiée en juillet de la seconde année et en octobre-novembre de la troisième. Les stades prévitellogénétiques (accumulation de RNA et de lipides) sont déjà présents à 14 mois d'âge, lorsque les prélèvements ont débuté. Au cours de la deuxième année d'âge, des accumulations limitées de vitellus sont observées dans les ovocytes, mais sans que le poids total des ovaires en soit modifié. Dans cette population, ce n'est que durant la troisième année d'âge que la vitellogenèse est complète et que l'ovulation intervient chez la plupart des femelles. Avant la fin du cycle, en octobre-novembre, on observe une augmentation notable des ovocytes prévitellogénétiques (stades 1-2 et 3). Elle est suivie dès décembre par une élévation des ovocytes contenant des " corps vitellins ", q̣ui représentent sans doute la classe d'ovocytes s'engageant dans le processus de vitellogenèse du cycle suivant. Le mode $d^{\prime i n i t i a t i o n ~ d e s ~} 1^{\text {er }}$ et $2^{\mathbf{e}}$ cycles vitellogénétiques apparaissent ainsi différents.

\section{Références}

AIDA K., LOU S. W., HANYU I., 1983. Reproductive activity of a twice-annually spawning strain of rainbow trout. Int. Symp. Salmonid Reprod., Seattle, 31 Oct.-2 Nov. 1983.

BAYNES S. M., SCOTT A. P., 1985. Seasonal variations in parameters of milk production and in plasma concentration of sex steroids of male rainbow trout (Salmo gairdneri). Gen. comp. Endocr., 57, 150-160. 
BEACH A. W., 1959. Seasonal changes in the cytology of the ovary and of the pituitary gland of the goldfish. Can. J. Zool., 37, 615-625.

BEAMS H. W., KESSEL R. G., 1973. Oocyte structure and early vitellogenesis in the trout, Salmo gairdneri. Am. J. Anat., 136, 105-122.

BILLARD R., 1974. La production spermatogénétique de la truite arc-en-ciel au cours du premier cycle reproducteur. Bull. Fr. Pisc., 253, 140-149.

BILLARD R., 1980. Reproduction and artificial insemination in teleost fish. $g^{\text {th }}$ int. Congr. Anim. Reprod. Artif. Insem., vol. II, 327-337.

BILLARD R., 1983a. Spermiogenesis in the rainbow trout (Salmo gairdneri). An ultrastructural study. Cell Tissue Res., 233, 265-284.

BILLARD R., 1983b. A quantitative analysis of spermatogenesis in the trout, Salmo trutte fario. Cell Tissue Res., 230, 495-502.

BILLARD R., BRETON B., JALABERT B., 1971. La production spermatogénétique chez la truite. Ann. Biol. anim. Bioch. Biophys., 11, 190-212.

BILLARD R., SOLARI A., ESCAFFRE A. M., 1974. Sur une méthode d'analyse quantitative de la spermatogenèse des téléostéens. Ann. Biol. anim. Bioch. Biophys., 14, 87-104.

BILLARD R., BRETON B., 1977. Sensibilité à la température des différentes étapes de la reproduction chez la truite arc-en-ciel. Cahiers Lab. Montereau, 5, 5-24.

BILLARD R., BRETON B., FOSTIER A., JALABERT B., WEIL C., 1978. Endocrine control of the teleost reproductive cycle and its relation to external factors : salmonid and cyprinid models, 37-48. In : GAILLARD P. J., BOER H. H., Comparative endocrinology. Elsevier/North Hollande biochem. Press, Amsterdam.

BOWERS A. B., HOLLIDAY F. G. T., 1961. Histological changes in the gonad associated with the reproductive cycle of the herring (Clupea harengus L.). Marine Res., 5, $16 \mathrm{pp}$.

BRETON B., BILLARD R., 1977. Effects of photoperiod and temperature on plasma gonadotropin and spermatogenesis in the rainbow trout Salmo gairdneri Richardson. Ann. Biol. anim. Bioch. Biophys., 17, 331-340.

BRETON B., FOSTIER A., ZOHAR Y., LE BAIL P. Y., BILLARD R., 1983. Gonadotropine glycoprotéique maturante et œstradiol-17 $\beta$ pendant le cycle reproducteur chez la truite fario (Salmo trutta) femelle. Gen. comp. Endocrinol., 49, 220-231.

BRETON B., ZOHAR Y., BILLARD R., 1985. Photoperiod and gonadotropin control of the reproductive cycle in the female rainbow trout, 1243-1246. Currents trends comp. Endocr. LOFTS B., HOLMES P., Hong Kong University Press, Hong Kong.

BROWN C. J. D., KAMP G. C., 1942. Gonad measurements and egg counts of brown trout (Sa/mo trutta) from the Madison river, Montana. Trans. Am. Fish Soc., 71, 195-200.

BUSSON-MABILLOT S., 1984. Endosomes transfer yolk proteins to lysosomes in the vitellogenic oocyte of the trout. Biol Cell, 51, 53-66.

FUNK J. D., DONALDSON E. M., DYE H. M., 1973. Induction of precocious sexual development in female pink salmon (Oncorhynchus gorbuscha). Can. J. Zool., 51, 493-500.

GREENE C., 1926. Physiological reviews. Phys. Rev., 6, 201-241.

HANSON J. A., WICKWIRE R. H., 1967. Fecundity and age at maturity of lake trout, Salvelinus numaycush (Walbaum) in lake Tahoe. Calif. Fish Game, 53, 154-164.

HENDERSON N. E., 1962. The annual cycle in the testis of the eastern brook trout, Salvelinus fontinalis (Mitchill). Can. J. Zool., 40, 631-641.

HICKLING C. F., 1930. The natural history of the hake. Part III. Seasonal changes in the conditions of the hake. Fish Invest. London, Ser. 2, Vol. 12, No 1. Ministry of Agriculture and Fisheries, London, pp. 1-78.

HIROI O., YAMAMOTO K., 1968. Studies on the maturation of salmonid fishes. I. Changes in the testis of the chum salmon Oncorhynchus keta during anadromous migration. Bull. Fac. Fish. Hokkaido Univ., 19, 173-184.

HIROI O., YAMAMOTO K., 1970. Studies on the maturation of salmonid fishes. Il. Changes in the testis of the masu salmon Oncorhynchus masou during anadromous migration. Bull. Fac. Fish. Hokkaido Univ., 20, 252-263.

HOAR W. S., NAGAHAMA Y., 1978. The cellular sources of sex steroids in teleost gonads. Ann. biol. anim. Bioch. Biophys., 18, 893-898. 
HONMA Y., TAMURA E., 1962. Seasonal changes in the gonads of the land-locked salmonid fish, Ko-ayu, Plecoglossus altivelis Temminck and Schlegel. Jap. J. Ichthyol, 9, 135-152.

HOOVER E. E., HUBBARD H. F., 1937. Modification of sexual cycle of trout by control of light. Copeia, 4, 206-210.

HURK R. Van den, PEUTE J., VERMEIJ J. A. J., 1978. Morphological and enzyme cytochemical aspects of the testis and vas deferens of the rainbow trout Salmo gairdneri. Cell Tissue Res., 186. 309-325.

HURK R. Van den, PEUTE J., 1979. Cyclic changes in the ovary of the rainbow trout, Salmo gairdneri, with special reference to sites of steroidogenesis. Cell. Tissue Res., 199, 421-440.

HTUN-HAN M., 1977. The effects of photoperiod on reproduction in fishes. An annotated bibliography. Library Information Leaflet MAFF. Lowestoff, 6, pp. 30.

IEVLEVA M. Y., 1970. Gametogenesis of young sokeye salmon (Oncorhynchus nerka Walb.) from Dal'nee lake. Proc. Pac. Sci. Res. Inst. Mar. Fish Ocean, 78, 81-104.

JONES J. W., 1940. Histological changes in the testis in the sexual cycle of male salmon parr (Salmo salar L.). Proc. roy. Soc., 128, 499-509.

KAZAKOV R. V., 1979. Dependence of sperm quality on frequency at which the atlantic salmon males are used as spawners at hatcheries. In : KASAKOVA (Ed.), Quality of brood stock and sexual products in fish, Gosniork, Leningrad, pp. 49-61.

LAMBERT J. G. D., 1969. Steroid production in the ovary of Poecilia reticulata. Ph. D., Utrecht Univ.

LARSON G. L., 1973. Liver weight of brook trout in a high-mountain lake in Washington state. Prog. Fish. Cult., 35, 234-236.

LUSK S., 1968. Changes in gonad weight and amount of fats in the brown trout Salmo trutta fario L., in the course of a year. Zool. List., 18, 67-80.

MAGRI M. H., 1980. Induction de la gamétogenèse chez la truite arc-en-ciel (Salmo gairdneri) immature. Dipl. Et. appr. Univ. Paris VI, pp. 18.

MARTIN V. N., 1970. Long-term effects of diet on the biology of the lake trout and the fishery in lake Opeongo, Ontario. J. Fish. Res, Bd Canada, 27, 125-146.

NAGAHAMA Y., CLARKE W. C., HOAR W. S., 1978. Ultrastructure of the putative steroidproducing cells in the gonads of coho (Oncorhynchus kisutch) and pink salmon (Oncorhynchus gorbuscha). Can. J. Zool., 56, 2508-2519.

NOMURA M., 1963. Studies on reproduction of rainbow trout Salmo gairdneri with special reference to egg taking. IV. The fecundity on number and weight of eggs taken. Bull. jap. Soc. Sci. Fish., 28, 1070-1076.

OOTA I., YAMAMOTO K., TAKANO K., SAKAGUCHI T., 1965. Studies on the maturing process of the rainbow trout, Salmo gairdneri irideus. II. Maturation of the testis of a one-year old fish. Bull. jap. Soc. Sci. Fish., 31, 597-605.

PANTIC V. P., LOVREN M., 1973. Gametogenesis in Serranus scriba (Teleostei). Gametogenese beim Schriftbarsch, Serranus scriba (Teleostei). Cytobiology, 7, 127-137.

SCOTT D. P., 1962. Effect of food quantity on fecundity of rainbow trout, Salmo gairdneri. J. Fish. Res. Bd. Canada, 19, 715-731.

SCOTT A. P., MacKENZIE D. S., STACEY N. E., 1984. Endocrine changes during natural spawning in the white sucker, Catostomus commersoni. II. Steroid hormones. Gen. comp. Endocr., 56. 349-359.

SCOTT A. P., BAYNES S. M., SKARPHEDINSSON O., BYE V. J., 1984. Control of spawning time in rainbow trout, Salmo gairdmeri, using constant long daylengths. Aquaculture, 43, $225-233$.

SHIKHSHABEKOV M., 1974. Feature of the sexual cycle of some semi-diadromous fishes in the lower reaches of the terek. J. Ichthyol., 14, 79-87.

SUMPTER J. P., SCOTT A. P., BAYNES S. M., WITTHAMES P. R., 1984. Early stages of the reproductive cýcle in virgin female rainbow trout (Salmo Gairdneri Richardson). Aquaculture, 43, 235-242.

SUZUKI K., 1939. Regeneration of gonads in Plecoglossus altivelis after spawning season. Cytologia, Vol. 10.

SZÖLLÖSI D., JALABERT B., BRETON B., 1978. Postovulatory changes in the theca folliculi of the trout. Ann. Biol. anim. Bioch. Biophys., 18, 883-891.

TAUBE C. M., 1976. Sexual maturity in brown trout of the Platte river, Michigan. Trans. am. Fish. Soc., 4, 529-533. 
UPADHYAY S. N., 1977. Morphologie des gonades immatures et étude expérimentale de l'induction de la gamétogenèse chez la truite arc-en-ciel juvénile (Salmo gairdneri R.). Thèse Doct. ès Sci. Nat. Univ. Paris VI, pp. 111.

UPADHYAY S. N., BRETON B., BILLARD R., 1978. Ultrastructural studies on experimentally induced vitellogenesis in juvenile rainbow trout (Salmo gairdneri R.) Ann. Biol. anim. Bioch. Biöphys., 18, 1019-1025.

VLADYKOV V. D., 1956. Fecundity of wild speckled trout (Salvelinus fontinalis) in Quebec lakes. J. Fish. Res. Bd. Canada, 13, 799-841.

WEISEL G. F., 1943. A histological study of the testes of the sockeye salmon (Oncorhynchus nerka). J. Morph., 73, 207-229.

WHITEHEAD C., BROMAGE N. R., FORSTER J. R. M., MATTY A. J., 1978. The effects of alterations in photoperiod on ovarian development and spawning time in the rainbow trout /Salmo gairdneri). Ann. Biol. anim. Bioch. Biophys., 18, 1035-1043.

WYDOSKI R. S., COOPER E. L., 1966. Maturation and fecundity of brook trout from infertile streams. J. Fish. Res. Bd. Canada, 23, 623-649.

WOODHEAD A. D., 1960. Nutrition and reproductive capacity in fish. Proc. Nutr. Soc., 19, $23-28$.

WOOTON R. J., 1979. Energy costs of egg production and environmental determinants of fecundity in teleost fishes. Symp. Zool. Soc. London, 44, 133-159. 